\title{
On the Hydrogeological Conditions of Western Herzegovina (Bosnia and Herzegovina) and Possibilities for New Groundwater Extractions
}

\author{
Ivan SLIŠKOVIĆ
}

Key words: Karst hydrogeology, Karst springs, Hydrogeological barriers, Groundwater use, High Karst, Dinaric Karst, Bosnia and Herzegovina

\section{Abstract}

Results of hydrogeological exploration carried out in the High Karst of western Herzegovina are reported. The hydrogeological map shows the hydrogeological function of the strata, together with full and partial barriers, and terrains of low and high permeability. The exploration indicates an increase in discharge rates from ascending springs after construction of the Salakovac and Tribistovo reservoirs $\mathrm{n}$ their hinterland. Areas promising for groundwater exploration xcur far from the zones of discharge. The chemical composition of groundwater in the upper part of the Tihaljina river indicates circulaion of deep groundwater and an associated increase in sulphate conent. The results of observations and measurements of many springs and groundwater tracing experiments are presented. This study has snabled the discovery of potable groundwater in karst areas previous$\mathrm{y}$ considered as dry.

\section{INTRODUCTION}

The exploration area comprises the drainage basin of the Mostarsko Blato and the Tihaljina river. It ncludes the Čvrsnica and Čabulja mountains and the ight bank of the Neretva river, from Jablanica to Jabela (Fig. 1).

The groundwater potential of this area has been icarcely explored or utilised although the basic data tbout major springs and streams were collected during reparation of the groundwater budget of the river veretva drainage basin. This includes data on the :prings used for water supply: Studenac and Radobolja lear Mostar, Vrilo at Grude, the springs at Studenci lear Ljubuški and the Vrioštica at Vitina (SLIŠKOVIĆ, 991).

Interpretation of existing data suggests that there is rroundwater in unexplored areas. Significant groundvater resources are expected in the following areas: Iortheast of the Ljubuški-Klobuk overthrust, along the Iorthwestern edge of the Imotsko-Bekijsko Polje, in the arst of Grab and Banja, along the northern edge of the Mostarsko Blato and in the karst plateau of ČitlukIamzići-Buhovo-Rasno (Fig. 2). By using appropriate nodern exploration methods, considerable amounts of

1stitute of Geology, Sachsova 2, P.O.Box 268, 41000 Zagreb, Croatia. unpolluted groundwater could be extracted during the hydrological minimum. This would have rather complex benefits and also a strategic significance, thus helping to attract more attention and funds for hydrogeological explorations in the next decade. This is of a particular interest for those areas in western Herzegovina where the water supply/demand problem is very acute, eg. the areas of Posušje, Čitluk, Grude and the northern and southern edge of the Mostarsko Blato.

\section{REVIEW OF PREVIOUS HYDROGEO- LOGICAL EXPLORATIONS}

The first explorations were associated with problems concerning the outflow from karst poljes through ponors (sinkholes) and zones of ponors (SREBRENOVIĆ, 1965; MIKULIĆ \& TRUMIĆ, 1969; RISTIĆ, 1975). JOSIPOVIĆ (1974) wrote about the hydrodynamic conditions of the karst medium. Karst areal subdivision was studied by JOSIPOVIĆ (1974), KOMATINA (1975) and SLIŠKOVIĆ (1983) on the basis of geotectonic conditions in the Dinarides, while Šarin's stud-

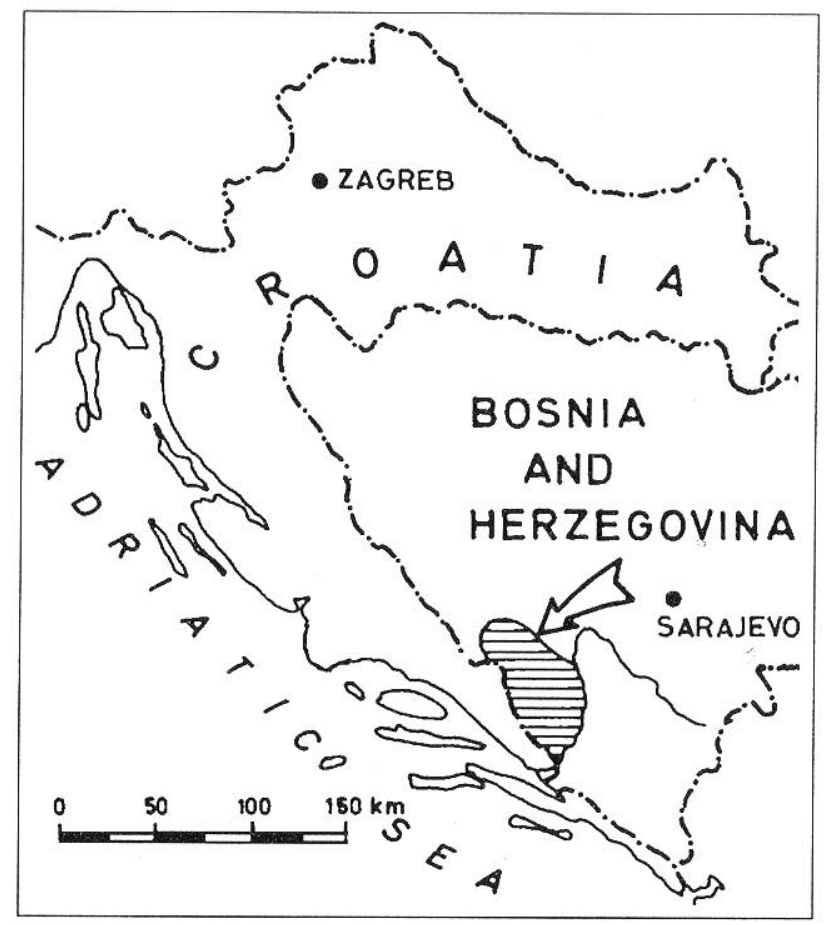

Fig. 1. Location map. 


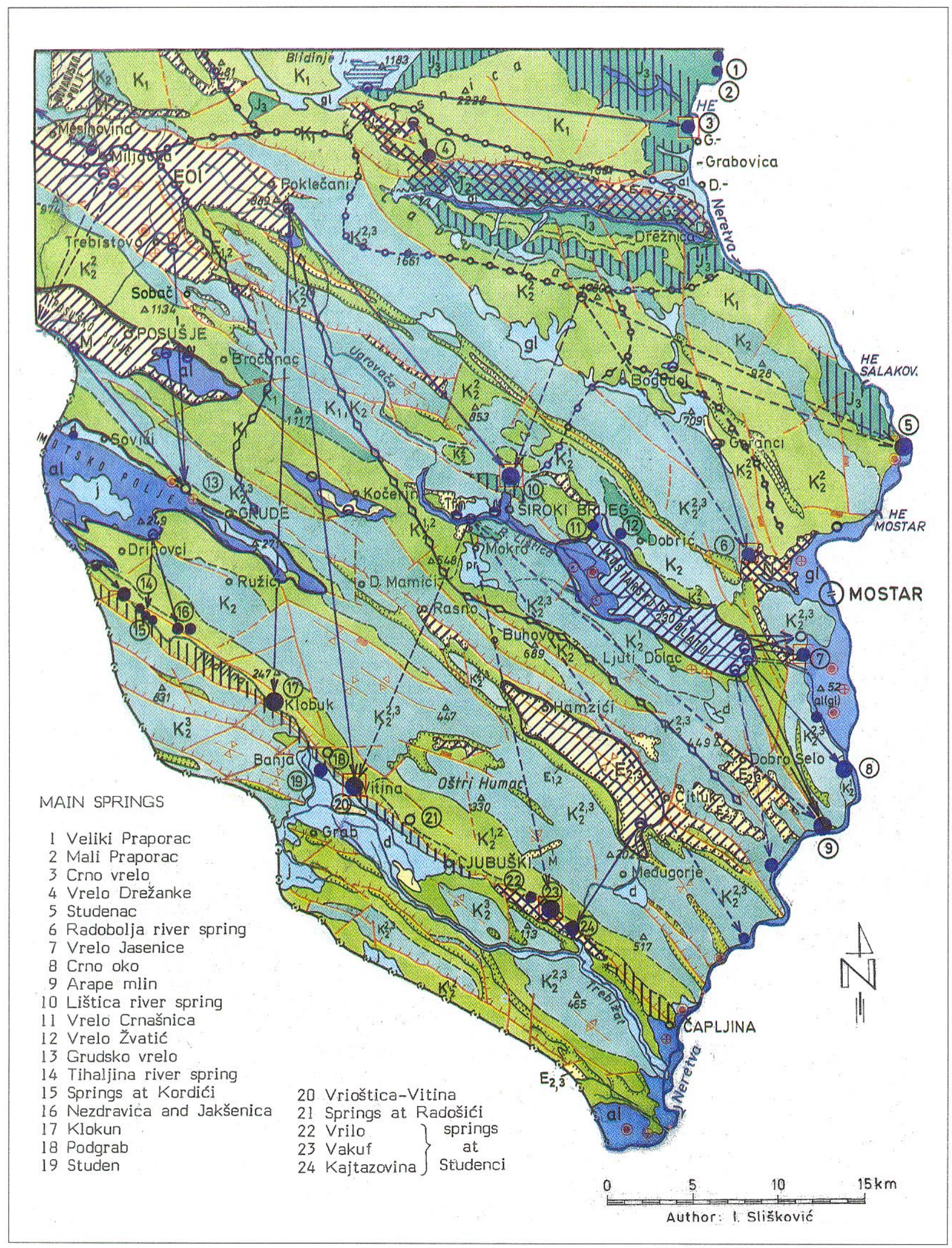

ies were centred on the regional hydrogeological characteristics of the Dinarides (ŠARIN, 1983, 1984).

According to purpose and type, previous hydrogeological explorations in western Herzegovina might be divided into:

- regional hydrogeological explorations, and
- detailed hydrogeological explorations.

The regional hydrogeological explorations were performed between 1964 and 1981, and were aimed at obtaining basic data about the hydrogeology of this area. Important karst springs were observed over a period of 2 to 3 years. From collected data, it was possible 


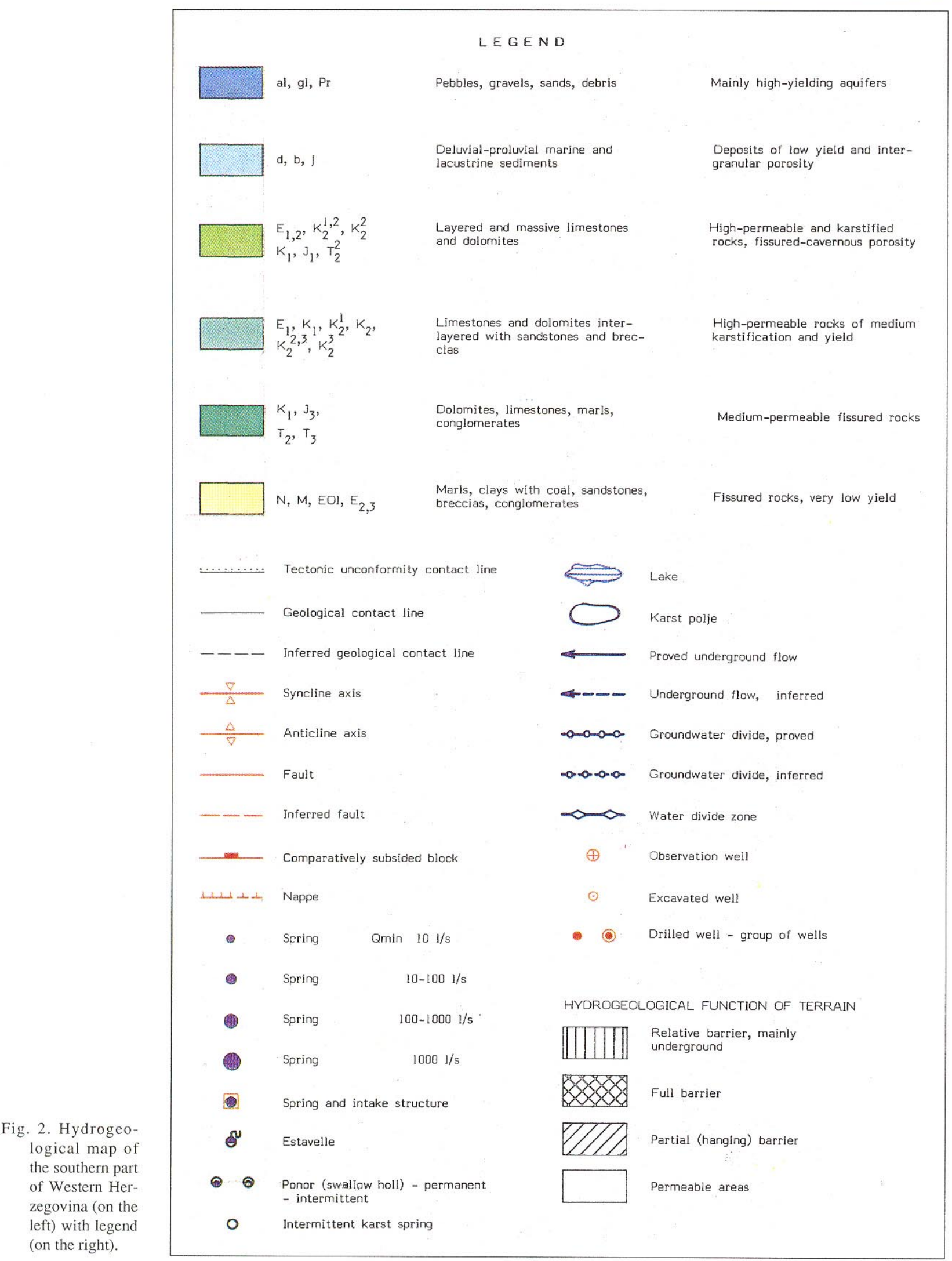

to define the hydrogeology of the study area and obtain bases for determining an approximate groundwater budget that included an estimate of the dynamic groundwater resources of karst aquifers. In addition, in order to determine the geometry of drainage basins, tracing experiments were carried out during high and medium groundwater stages. The groundwater budgets were determined for 1978 to 1981 and they comprised the following springs: along the Drežanka river, those occurring along the right side of the Neretva river between the towns of Jablanica and Čapljina, those in the drainage basin of Mostarsko Blato and the springs 
of the rivers Tihaljina and Studenčica (SLIŠKOVIĆ, 1983').

Detailed explorations for the municipal and industrial water supply were performed in the areas expected to have abundant groundwater. Many unsolved problems with the water supply has resulted in annual increases in the need for detailed explorations. Most towns (Mostar, Široki Brijeg, Ljubuški, Čapljina, Grude) and villages of western Herzegovina use neighbouring springs for their water supply. The intake structures of these springs were mainly constructed prior to hydrogeological exploration. Recently, hydrogeological explorations using geophysical, thermometric and geochemical methods, hydrogeological observations and exploratory drilling have been applied.

The Commune of Grude had experienced considerable difficulties with their water supply untill a thorough hydrogeological study of its intermittent spring, the Grudsko Vrelo, was carried out. Exploration by the Geofizika company of Zagreb in $1971^{2}$ and the Geoinženjering of Sarajevo in $1984^{3}$ helped to solve a long-time water supply problem. Groundwater is extracted by wells $60 \mathrm{~m}$ deep. The evaluated resources for low water stage are about $200 \mathrm{1} / \mathrm{s}$ which is sufficient for the whole Commune of Grude water supply.

The exploration for reclamation and irrigation purposes were complex and undertaken either simultaneously with or separately to exploration for hydro power plants, particularly those in individual karst poljes. The Imotsko-Bekijsko Polje is under the main construction design stage, while feasibility studies are being undertaken in order to find a solution for the problems of the Mostarsko Blato and other smaller poljes, such as the Rakitno, Posuško, Čitlučko, Kočerin, Mokro and Trn Poljes (DŽEMAL \& ZAHIROVIĆ, 1985).

The capacity of ponors occurring at the edges of karst poljes during high and medium groundwater stages, are lower than the discharge rates of springs and estavelles that results from periodic inundations of those poljes. Thus, the poljes provide natural water retention for downstream springs (RISTIĆ, 1975). For the reclamation of those poljes and preparation for intensive agriculture, the reservoirs should be constructed upstream and drainage tunnels downstream. For these constructions, comprehensive geological, hydrogeological and hydrological explorations are necessary in order not to disturb groundwater resources of downstream water supply constructions.

The hydrogeological exploration for mining purposes was undertaken at Mostar to facilitate the drainage of a brown coal mine and at Studena Vrila for drainage of a bauxite mine. At present, work in these mines is being carried out more or less effectively (SLIŠKOVIĆ, 1984).

\section{GEOLOGICAL REVIEW}

The study area is composed of sedimentary rocks of Permo-Triassic, Triassic, Jurassic, Cretaceous, Palaeogene, Neogene and Quaternary age. The PermoTriassic sediments have been tectonically lifted to the land surface at Sobač and consist of gypsum and anhydrites. The undifferentiated Middle and Lower Triassic is composed mainly of dolomites and dolomitic limestones in the region of Čvrsnica Mountain and along the northern slopes of Čabulja Mt. The Jurassic limestones and dolomites are found in the central region of the river Drežanka. The Cretaceous deposits are complete and cover the largest area. They are composed of stratified to massive limestones with rare dolomites (Fig. 2). Tertiary sediments cover a considerably smaller area. The Palaeogene outcrops in small areas and consists of marly and sandy limestones in the lower part, alveolinid and nummulitic limestones in the central part, and clastic sediments in the upper part. The Miocene and Pliocene sedimentary rocks were deposited in a freshwater environment. The Quaternary deposits extend along the rivers Neretva and Trebižat and in karst poljes.

The study area is characterized by intensive tectonics as revealed through the presence of folding, flexure stretching, faulting and imbricated structures. The strike of the major structures and deformations is northwestsoutheast, while faults trending north-south are also common. The following structural units can be differentiated within the study area: the Svitava-Ljubuški and Stolac-Čitluk units, the Imotski subunit and the Udrežnje-Mostar-Lištica unit.

\section{THE HYDROGEOLOGIGAL FUNCTION OF TERRAINS AND DRAINAGE BASINS}

Western Herzegovina belongs to one of the High Karst zones; the Orogenic Accumulated Karst (HERAK, 1977), characterized by the development of specific geomorphologic, geological and hydrogeological features. The hydrogeological map (Fig. 2) shows the hydrogeological function of rocks, their permeability and hydrogeological phenomena. The rocks and terrains are classified on the basis of the type and degree of permeability according to the genetic and sedimentologic characteristics of the sediments, as interpreted from previous exploration data.

\footnotetext{
I SLIŠKOVIĆ, I. (1983): Hidrogeološka rajonizacija i bilans podzemnih voda u pukotinskim i kraško pukotinskim stijenskim masama Bosne i Hercegovine.- Unpublished study report, Geoinstitut, Sarajevo, 280 p.

2 ANON. (1971): Geofizički i bušaći radovi na Grudskom vrelu.- Unpublished tech. report, Geofizika, Zagreb.

3 SLIŠKOVIĆ, I. (1984): Hidrogeološki istražni i kaptažni radovi za potrebe vodoopskrbe Grudske općine.- Unpublished tech. report, Geoinženjering, Sarajevo.
} 
Limestones are the predominant rock units in this region. Within them, fissures and other openings are very heterogeneous and reflect the tectonic processes which occurred during the Alpine orogeny. Limestones, dolomitic limestones and some dolomites are classified as high-permeable rocks with cavernous and fissured porosity. The permeability of these rocks depends on their karstification, intensity and density of fissures, structural position, stratification, formation thickness and the relative proportions of their calcitic and dolomitic components.

Dolomites occur of different ages, from the Lower Triassic to Upper Cretaceous, and range from pure dolomites in the central part of the Neretva river, through a gradual transition to pure limestones in the area of Posušje and Široki Brijeg. The Upper Triassic dolomites are occasionally karstified but, as a formation, they are impermeable and form barriers to groundwater flows. Dolomites play a significant role in the formation of water divides in the central Neretva river, in the area of Diva Grabovica and Drežnica. The drainage basin of Veliki Praporac and Mali Praporac is confined toward the north and south by the dolomites of the rivers Doljanka and Drežanka while the western border is obscure. The drainage basin of Veliki Praporac and Mali Praporac is separated from the basin of Crno Vrelo by the dolomitic anticline of Diva Grabovica.

Jurassic and Cretaceous dolomites are relatively insignificant contributors to the impermeability of rock complexes but, if they form the core of anticlines, they function as barriers to groundwater flows. The Lower Cretaceous dolomites of the river Lištica spring are of this type.

Palaeogene and Neogene clastic sediments, deposited in basins of different age and origin, are considerably more important factors in the flow of groundwater. During the Illyrian orogeny, the Palaeogene sediments were lifted, repeatedly folded and simultaneously overthrusted by Upper Cretaceous deposits, resulting in the inclination of the synclines toward the southwest. The sea bottom subsided during the Lower Miocene, and Neogene sediments were subsequently deposited. Pliocene and Quaternary neotectonic movements produced the current morphology of this area.

By the end of Pliocene and early Pleistocene, certain poljes and plateaus underwent heavy tectonism during which karst poljes were formed without marine or lacustrine deposition. Examples include the Imotsko and Dugo Poljes in the north and northwest and the Mostarsko Blato in the south of the area of study. The karst poljes are at different altitudes in western Herzegovina. From the Kupreško Polje (1150 m above sea level), they descend to the Duvanjsko Polje (800 m) and Livanjsko Polje $(720 \mathrm{~m})$ toward the river Cetina at the southwestern side, and to the Posuško polje (600 $\mathrm{m})$, Imotsko Polje (250 m) and Mostarsko Blato (240 m above sea level) toward the river Neretva drainage basin at the southeastern side of this area.
The drainage area of the lower Neretva river, to the river Trebižat, is very narrow because the drainage basin of the Mostarsko Blato is considered as a separate drainage area. Attempts to define the divide of the Mostarsko Blato drainage basin have been futile because the underground divide is, most probably, mainly zonal. Groundwater flow tracing in this large drainage basin is lacking and more attention should be focused on this problem in the future.In the northern part of the drainage basin, the relationships with neighbouring drainage basins are more obvious because the impermeable rocks along the Drežanka river occur in an anticline, thus directing groundwater flow towards the south. The northwestern divide is approximately defined by tracing of the ponor (swallow hole) Miljacka at the Studena Vrela springs and by the position of roofwall deposits north of Poklečani.

Tracing in the Rakitsko Polje proved that the divide with the river Trebižat is a wide zone. Within this expressly karst area, the Upper Cretaceous dolomites are often permeable because they occur within imbricated structures. The Upper Cretaceous anticline, in the Šroki Brijeg area, is the reason for the appearance of the major karst spring of the Lištica river. Water from the northwestern area flows out from this spring.

KOMATINA (1975) postulates that, in the dry season, groundwater flows toward the springs of the river Tihaljina, thus explaining the existence of the intermittent river Ugrovača by which most of surface water flows toward the Mostarsko Blato during the rainy season.

New tracing experiments are necessary to prove to which drainage basin the groundwater of minor Neogene poljes (Kočerin, Trn and Mokro Polje) pertains. At present, it is most logical to consider that this water belongs to the drainage basin of the springs Crno Oko, Arapa Mlin and the Jasenica river spring.

Palaeogene and Neogene deposits in the west of the study area form a significant barrier. In addition, narrow Palaeogene zones extending from the Neretva river toward the northwest act as hanging barriers to groundwater flow. The best known full barrier occurs at the front of the Ljubuško-Klobuk overthrust and it extends along the left bank of the Tihaljina river. The area from Mostar to Čitluk and Hamzići is composed of hanging barriers which extend in several zones up to the Duvanjsko Polje. Impermeable rock units occur at high levels and act as hanging barriers to groundwater formed in the deep karst.

\section{HYDROGEOLOGICAL PHENOMENA AND GROUNDWATER RESOURCES}

The immediate drainage basin of the part of the river Neretva occurring downstream of Jablanica is recharged by water that flows from the Veliki Praporac and Mali Praporac springs (Fig. 2, springs 1 and 2). It is very difficult to accurately measure their rates of dis- 
charge, but their mean value is estimated at slightly in excess of $2.5 \mathrm{~m}^{3} / \mathrm{s}$.

The Crno Vrelo spring (No. 3 in Fig. 2) appears in a small ponikva (doline, sinkhole) and water emerges from two parallel vertical fissures. Several metres above the spring, there is a spelaelogical lake. Water flows from the cave after periods of heavy rain or rapid thaw. The extreme discharge rates are 1 and $50 \mathrm{~m}^{3} / \mathrm{s}$.

The Drežanka river drainage basin is composed of monoclinal Triassic dolomites. After groundwater tracing from a ponor at Donje Bare, the underground hydraulic connection was determined with the Drežanka river spring (No. 4) situated at the northwestern end of the river canyon.

The Studenac spring (No. 5) emerges $0.5 \mathrm{~m}$ above the mean Neretva river stage. This spring was explored in detail in order to prevent possible degradation as a result of construction of the power plant "Mostar" on the Neretva river. This spring is very important because its water is used for the water supply of Mostar. Around the spring, 35 observation boreholes and 5 pumping wells were drilled. A siphonal type of spring was discovered. Part of its water flows out into the Neretva river not far from the main spring. Simultaneous measurements and the correlation of flow rates showed that, after filling the Salakovac power plant reservoir, the minimum spring discharge doubled; it increased from 1.2 to $2.4 \mathrm{~m}^{3} / \mathrm{s}$. This indicates a direct hydraulic connection with the part of Neretva river situated upstream of the Bijelo Polje.

The spring of the river Radobolja (No. 6) is recharged from the karst of the southeastern part of Čabulja Mt. Groundwater flows through carbonate aquifers along two faults striking northwest-southeast. The fault that extends from Goranci toward the river Radobolja spring conducts water directly into the spring, near the contact with Neogene clastics. The spring discharge rate fluctuates considerably: $\mathrm{Q}_{\max }>10$ $\mathrm{m}^{3} / \mathrm{s}, \mathrm{Q}_{\text {mean }}=3 \mathrm{~m}^{3} / \mathrm{s}, \mathrm{Q}_{\min }=0.2 \mathrm{~m}^{3} / \mathrm{s}$.

The Mostarsko Blato is periodically inundated by the intermittent stream Ugrovača and permanent springs occurring at Lištica, Crnašnica and Zvatić. The springs of Lištica (No. 10) appear in a zone $200 \mathrm{~m}$ long and have a total minimum discharge of $3.0 \mathrm{~m}^{3} / \mathrm{s}$. The groundwater that flows from these springs accumulates in the subsurface over an area of about $220 \mathrm{~km}^{2}$ northward and northwestward of the spring (SLIŠKOVIĆ, 1983).

The springs of Crnašnica (No. 11) and Žvatić (No. 12) occur at the northern edge of the Mostarsko Blato and their appearance is the result of the presence of Upper Cretaceous dolomites. Neogene clastics also outcrop here and they, together with the dolomites act as a barrier to groundwater flow. The minimum total discharge of the springs at Crnašnica is $30 \mathrm{l} / \mathrm{s}$ and at Žvatić $10 \mathrm{l} / \mathrm{s}$. During the period of high groundwater stages, intermittent springs appear around the permanent springs of Žvatić.

The Mostarsko Blato is flooded 6 to 7 months of the year on average. Due to flood water damage, a drainage tunnel was excavated from the village of Čule to the river Jasenica in 1947, and its capacity is $23 \mathrm{~m}^{3} / \mathrm{s}$ (ĐUROVIĆ, 1964). Despite this, the polje is still flooded because the flow capacity of the river Jasenica is too low. The capacity of ponors in the Mostarsko Blato depends on the water level in the polje. When the flood stage is $1 \mathrm{~m}$ high, the ponors remove $4.8 \mathrm{~m}^{3} / \mathrm{s}$; when it is $4 \mathrm{~m}$ high, they intake $14.5 \mathrm{~m}^{3} / \mathrm{s}$; while at maximum flood stages, when the water level is $11 \mathrm{~m}$ high, the flow capacity of ponors is $27.5 \mathrm{~m}^{3} / \mathrm{s}$. The ponors situated along the northeastern edge of the polje are connected with the Jasenica river spring (No. 7) while the ponor Orlinjača occurring at the eastern edge of the polje is hydraulically connected with the springs Crno Oko (No. 8) and Arape Mlin (No. 9).

The area surrounding the river Jasenica, south of Mostar, is composed of Quaternary conglomerates and gravels up to $30 \mathrm{~m}$ thick, which hold a large quantity of groundwater.

The Crno Oko (No. 8) is a typical ascending siphonal spring and emerges from a small ponikva which is only $7 \mathrm{~m}$ wide and some $10 \mathrm{~m}$ deep. At the bottom, the ponikva extends into a cave. The minimum spring rate of discharge is about $0.8 \mathrm{~m}^{3} / \mathrm{s}$.

The Arape Mlin spring, $Q_{\min }=0.14 \mathrm{~m}^{3} / \mathrm{s}$, appears $2.5 \mathrm{~km}$ southward of the Crno Oko, where water springs from calcareous debris $1.5 \mathrm{~m}$ above the highest Neretva river stage. There is a major karst spring at Žitomislić; the Dunajac. It has been studied in order to utilise it for extraction for the water supply $\left(Q_{\min }=15\right.$ $1 / \mathrm{s})$.

The river Trebižat changes its name four times. From its source in the Imotsko Polje to the river mouth, they are: the Vrlika, Tihaljina, Mlada and Trebižat. Since its drainage basin begins in Croatia, its northwestern and western divide will be described below.

The hydrogeological conditions of the ImotskiPosušje area have been described by PETRIK (1960). He interprets the hydrogeology of the western part of the Imotsko-Polje as three separate water regimes; the lakes Modro Jezero and Crveno Jezero, Blato (ponikvas around Blato and water table in the area of production wells I and II) and the river Vrlika spring. The author considers that the Springs of Vrlika (the Opačac and others) to be entirely independent of the lakes and groundwater at Blato. This opinion is supported by the fact that water flows from the springs when the lake water level is considerably lower than that of the springs. The minimum lake stages are 18 to $29 \mathrm{~m}$ lower than the land surface of the Imotsko Polje. This indicates a complexity of hydrogeological conditions in this part of the drainage basin. Other authors (BOJANIĆ et al., 1981) also describe the hydrogeological conditions of the Imotsko Polje. They suggest that the Krenica lake receives water from its rocky bottom and that the Quaternary deposits are about $40 \mathrm{~m}$ thick there. Their opinion is that the Quaternary deposits mostly act as a barrier controlling some water points in the polje and 
direct groundwater flow laterally and beneath the barrier toward the lower karst poljes. This suggestion was proven by groundwater tracing from the area of Tribistovo Polje and Posuško Polje (Mrke Stine).

In addition to the river Vrlika spring $\left(Q_{\text {mean }}=13\right.$ $\mathrm{m}^{3} / \mathrm{s}$ ), a major intermittent spring at Grade is important for water supply purposes. This spring is of a descending-ascending type. Water emerges from several open pits on a $70 \mathrm{~m}$ long line, $Q_{\text {mean }}=2.6 \mathrm{~m}^{3} / \mathrm{s}$. The spring is dry 3 to 4 months of the year. The surface stream formed by the spring water sinks through several ponors. The exploration showed that the water table falls from 10 to $30 \mathrm{~m}$ below the land surface. Two production wells were drilled in the 1970's yielding a combined capacity of $40 \mathrm{l} / \mathrm{s}$ and two more in 1984 which gave an additional $200 \mathrm{l} / \mathrm{s}$ for the water supply of the Grude commune, which will cover the demand of that commune for the next 30 to 40 years (SLIŠKOVIĆ, 19843).

After the construction of a surface water storage facility in the Tribistovo Polje, the spring at Grude discharges twice the previous volume of water. Meanwhile, only a long monitoring scheme can accurately prove this.

The Vrlika river sinks entirely at the village of Drinovci and emerges again in the spring of the Tihaljina river (the Peć Mlin, No. 14). Beneath the spring are dolomites forming the core of an anticline. Groundwater, from the Šainovci ponor, probably flows toward the springs at Kordići (No. 15). The mean flow rate of the river Vrlika at Šainovci is $12.6 \mathrm{~m}^{3} / \mathrm{s}$, while that of the river Tihaljina at the village of Tihaljina is $14.1 \mathrm{~m}^{3} / \mathrm{s}$. This increase in flow rate is caused by sinking of part of water of the spring at Grude that recharges the springs at the village of Kordići.

The river Tihaljina, between the villages of Kordići and Vitina, receives water at its left side from several permanent and intermittent springs and from the springs at Kordići (No. 15). The total minimum discharge rate of these springs is $60 \mathrm{l} / \mathrm{s}$ while the maximum exceeds 7 $\mathrm{m}^{3} / \mathrm{s}$. Downstream, the Tihaljina river receives water from three karst springs: the Nezdravica, Jakšenica and Nenoća and their minimum rates of discharge are 15 , 12 and $10 \mathrm{l} / \mathrm{s}$, respectively.

At the small town of Klobuk, only $80 \mathrm{~m}$ from the river Tihaljina, the largest karst ascending spring in western Herzegovina appears (the Klokun, No. 17). Its minimum, mean and maximum rates of discharge are: $3.6,7.5$ and $19.4 \mathrm{~m}^{3} / \mathrm{s}$, respectively. The spring is ascending and siphonal. It emerges in Cretaceous dolomites and its drainage basin is estimated about $260 \mathrm{~km}^{2}$ (SLIŠKOVIĆ, 19831).

Downstream of Klobuk, the karst springs are associated with the thrusting of Cretaceous limestones over Eocene flysch along the front of the Ljubuški-Klobuk overthrust. A row of karst springs begins with the intermittent spring Podgrab (No. 18). Its maximum discharge rate is over $5 \mathrm{~m}^{3} / \mathrm{s}$. It is dry 2 to 3 months of the year. The spring is of an overflowing type, thus a large quantity of water might be obtained from drilled wells if they are located in the hinterland.

At Vitina, where the river Trebižat becomes the Mlada, water from the spring Vrioštica (No. 20) and downstream, at the village of Radišići, from the Vrelo (No. 21) flows into the river. The discharge rates of the spring Vrioštica are: $\mathrm{Q}_{\min }=1.3, \mathrm{Q}_{\text {mean }}=3.2$ and $\mathrm{Q}_{\max }=$ $16 \mathrm{~m} 3 / \mathrm{s}$. Flow rate measurements at the river gauges Humac and Grab show that the mean discharge rate of the Vrioštica spring and of the permanent spring Studen (No. 19) and intermittent springs at the village of Radišići (No. 21), when combined, amounts to 6.9 $\mathrm{m}^{3} / \mathrm{s}$.

At the village of Studenci, the river Trebižat receives water from the stream Studenčica. This is a combination of the water of several karst springs among which the Vrilo (No.22), Vakuf (No. 23) and Kajtozovina (No. 24) are notable. The springs appear at the contact between Cretaceous limestones and Eocene flysch in a zone $2 \mathrm{~km}$ long. The spring Vakuf occurs at the lowest altitude and has a very low variation in flow discharge rates $\left(\mathrm{Q}_{\min }=2.0, \mathrm{Q}_{\text {mean }}=3.5\right.$ and $\mathrm{Q}_{\max }=5.1$ $\mathrm{m}^{3} / \mathrm{s}$ ), a beneficial fact for the water supply of the large Ljubuški-Čitluk region.

\section{GROUNDWATER RESERVES}

The groundwater reserves were determined by processing the data collected during earlier phases of hydrogeological exploration and observation. Hydrological observations at individual springs and groups of springs were very heterogeneous. So, from the springs shown in Fig. 2, the springs of the rivers Lištica (No. 10) and Radobolja (No. 6), the spring Studenac (No. 5) and the springs at the village of Studenci (No. 22, 23, 24) were monitored in the last 10 years; while the springs Crno Vrelo (No. 3), Crno Oko (No. 8), the river Drežanka spring (No. 4), the spring of Grude (No. 13) and other springs were observed over two or three years, during the period 1978-1981. Therefore, the accuracy of all data is not equal and the computed reserves are the result of an assumed degree of accuracy. Thus, the data on groundwater reserves presented in this paper may be used only as a basis for future, better determinations of reserves when the observation system and the knowledge of related facts will be more precise.

In Table 1, the total minimum and mean groundwater reserves and the pertaining drainage areas are given. The reserves were computed from the observed water table elevations, river stages and flow rates and by using various hydrogeological and geophysical exploration results (SLIŠKOVIĆ, 1983¹).

Taking into account the hydrogeological and morphological conditions of the studied part of western Herzegovina, this region can be divided into five drainage basins, those of:

- the springs Veliki Praporac, Mali Praporac and Crno 


\begin{tabular}{|c|c|c|c|c|c|c|c|c|c|}
\hline \multirow[b]{2}{*}{ No. } & \multirow{2}{*}{$\begin{array}{l}\text { DRAINAGE BASIN } \\
\text { SPRING NAME* }\end{array}$} & \multirow[b]{2}{*}{$\mathrm{km}^{2}$} & \multicolumn{2}{|c|}{ Flow rate } & \multicolumn{2}{|c|}{ Renewable reserves } & \multirow{2}{*}{$\begin{array}{l}\text { Admitted } \\
\text { extraction } \\
10^{6} \mathrm{~m}^{3 / \text { year }}\end{array}$} & \multirow{2}{*}{$\begin{array}{l}\text { Recession } \\
\text { coefficient }\end{array}$} & \multirow{2}{*}{$\begin{array}{c}\text { Residual } \\
\text { storage } \\
10^{6} \mathrm{~m}^{3}\end{array}$} \\
\hline & & & $\begin{array}{c}\text { Minimum } \\
\mathrm{m}^{3} / \mathrm{s}\end{array}$ & $\begin{array}{l}\text { Mean } \\
\mathrm{m}^{3 / \mathrm{s}}\end{array}$ & $\begin{array}{l}\text { Minimum } \\
10^{6} \mathrm{~m}^{3} / \text { year }\end{array}$ & $\begin{array}{c}\text { Total } \\
10^{6} \mathrm{~m}^{3} / \text { year }\end{array}$ & & & \\
\hline \multirow[t]{4}{*}{1} & Veliki Praporac (1) & & 0.400 & 1.920 & 12.60 & 60.48 & 12.60 & 0.022 & 1.550 \\
\hline & Mali Praporac (2) & & 0.140 & 0.750 & 4.41 & 23.62 & 4.41 & 0.020 & 0.640 \\
\hline & Crno Vrelo (3) & & 0.800 & 4.800 & 25.20 & 151.20 & 25.20 & 0.025 & 3.970 \\
\hline & TOTAL & 190 & 1.340 & 7.470 & 42.21 & 235.31 & 42.21 & & 6.160 \\
\hline 2 & Vrelo Drežanke (4) & 144 & 0.150 & 2.180 & 4.72 & 68.67 & 4.72 & & 0.369 \\
\hline \multirow[t]{3}{*}{3} & Studenac (5) & & 1.200 & 4.160 & 37.80 & 131.04 & 44.10 & 0.018 & 5.750 \\
\hline & Radobolje River spring (6) & & 0.200 & 1.030 & 6.30 & 32.44 & 6.30 & 0.021 & 0.830 \\
\hline & TOTAL & 168 & 1.400 & 5.190 & 44.10 & 163.48 & 50.40 & & 6.580 \\
\hline \multirow[t]{8}{*}{4} & $\begin{array}{l}\text { MOSTARSKO BLATO (POLJE) } \\
\text { AND JASENICA RIVER } \\
\text { DRAINAGE BASIN }\end{array}$ & & & & & & & & \\
\hline & Vrelo Lištice (10) & & 3.000 & $8.200^{* *}$ & 94.50 & 258.30 & 78.79 & 0.035 & 7.400 \\
\hline & Vrelo Crnašnice (11) & & 0.030 & $0.450^{* *}$ & 0.94 & 14.17 & 0.94 & 0.009 & 0.280 \\
\hline & Vrelo Žvatić (12) & & 0.010 & $0.600^{* *}$ & 0.31 & 18.90 & 0.31 & 0.008 & 0.097 \\
\hline & Vrela Jasenice (7) & & 0.400 & 12.500 & 12.60 & 393.75 & 12.60 & 0.021 & 2.026 \\
\hline & Crno Oko (8) & & 0.900 & 2.400 & 28.35 & 75.60 & 28.35 & 0.024 & 3.240 \\
\hline & Arape mlin (9) & & 0.140 & 0.500 & 4.41 & 15.75 & 4.41 & 0.020 & 0.640 \\
\hline & TOTAL & 420 & 4.480 & 15.400 & 141.12 & 485.10 & 125.36 & & 13.683 \\
\hline \multirow[t]{13}{*}{5} & $\begin{array}{l}\text { TIHALJINA (TREBIŽAT) } \\
\text { RIVER BASEN }\end{array}$ & & & & & & & & \\
\hline & Grudsko vrelo (13) & & 0.000 & 2.600 & 0.00 & 81.90 & 6.30 & - & - \\
\hline & Tihaljine River spring (14) & & 1.200 & 14.080 & 37.80 & 444.52 & $0.00^{* * *}$ & 0.031 & 3.344 \\
\hline & Springs at Kordići (15) & & 0.060 & 0.650 & 1.89 & 20.47 & $0.00 * * *$ & 0.008 & 0.664 \\
\hline & Nezdravica and Jakšenica (16) & & 0.040 & 0.480 & 1.26 & 15.12 & $0.00^{* * *}$ & 0.009 & 0.384 \\
\hline & Klokun (17) & & 3.680 & 7.500 & 115.92 & 236.25 & 0.63 & 0.052 & 9.936 \\
\hline & Podgrab (18) & & 0.000 & 1.200 & 0.00 & 37.80 & 0.00 & - & - \\
\hline & Studen (19) & & 0.400 & 1.400 & 12.60 & 44.10 & 12.64 & 0.021 & 2.026 \\
\hline & Vrioštica - Vitina (20) & & 1.250 & 3.400 & 39.37 & 107.10 & 25.25 & 0.019 & 5.678 \\
\hline & Spring at Radišići (21) & & 0.000 & 0.310 & 0.00 & 9.76 & 0.00 & - & 0.000 \\
\hline & Springs at Studenci $(22,23,24)$ & & 3.340 & 7.600 & 105.21 & 239.40 & 74.35 & 0.034 & 8.487 \\
\hline & TOTAL & $980+280$ & 9.970 & 36.620 & 314.05 & 1151.53 & 119.27 & & 30.519 \\
\hline & GRAND TOTAL & 2182 & 17.360 & 66.860 & 546.21 & 2106.09 & 341.96 & & 57.311 \\
\hline
\end{tabular}

Table 1. Estimated minimum and total dynamic groundwater reserves. Legend: * - spring number in the map (Fig. 2); ** - mean discharge rate of these springs is not included into their renewable reserves because it is included into those of the springs No. 7,8 and $9 ; * * *-$ spring water of low-quality for water supply because of a high sulphate content.

Vrelo (No. 1 to 3 );

- the spring Velika Drežnica and the river Drežnica spring (No. 4);

- the spring Studenac and the river Radobolja spring (No. 5 and 6);

- the polje Mostarsko Blato (10 to 12) and the associated springs in the Neretva river valley: Jasenica, Crno Oko and Arape Mlin (No. 7 to 9);

- the river Tihaljina spring and the associated drainage areas of the Poljes: Imotsko, Tribistovo and Rakitno (No. 13 to 24).

The groundwater reserves are not classified according to their categories, but the data on the safe yield of springs suitable for water supply are given (Table 1). The total water supply/demand of this region amounts to about 110 million $\mathrm{m}^{3} /$ year while the extraction potential is three times greater (the safe yield or total exploitable $\mathrm{Q}_{\min }=342$ million $\mathrm{m}^{3} /$ year). Meanwhile, the groundwater does not emerge where it is required; large areas are arid. For this reason, the "hidden" groundwater reserves occurring near the cites where they could be used are shown in the following review:

1 - Veliki Praporac (No. 1, Fig. 2), $Q_{\min }=0.4 \mathrm{~m}^{3} / \mathrm{s}$, is used for the water supply of Jablanica, at $Q \approx 0.1 \mathrm{~m}^{3} / \mathrm{s}$, would ensure this town will not demand more drinking water for a long time. Mali Praporac (No. 2) and Crno Jezero (No. 3) flow out free into the river Neretva because there are no consumers.

2 - The spring of Drežanka river (No. 4): only 0.002 $\mathrm{m}^{3 / \mathrm{s}}$ is used for public water supply and $0.1 \mathrm{~m}^{3} / \mathrm{s}$ for 
irrigation.

3 - The drainage basins of the spring Studenac (No. 5) and of the river Radobolja spring (No. 6), having combined $\mathrm{Q}_{\min }=1.4 \mathrm{~m}^{3} / \mathrm{s}$ under natural conditions and additional $1.2 \mathrm{~m}^{3} / \mathrm{s}$ after filling the hydro power reservoir Salakovac, offer a safe water supply for Mostar and its surroundings.

4 - The drainage basin of the Mostarsko Blato, with its $\mathrm{Q}_{\min }=3.04 \mathrm{~m}^{3} / \mathrm{s}$, gives enough water for the existing regional water supply system, but the water supply of peripheral settlements has not yet been solved. During an exploratory drilling along the northern and southern edges of the Mostarsko Blato, groundwater was found in limestones at depths of 20 to $70 \mathrm{~m}$. Since these sections are a "transit" area for groundwater flow toward the springs Crno Oko and of the river Jasenica, one may expect considerable reserves of the "hidden" groundwater. Groundwater flow from the direction of the Kočerin Polje indicates large amounts of such groundwater reserves in Cretaceous limestones along the southern edge of the Mostarsko Blato.

5 - Minimal dynamic reserves of all the springs of the Tihaljina river (total $\mathrm{Q}_{\min }=9.97 \mathrm{~m}^{3} / \mathrm{s}$ ) indicate significant residual reserves in the hinterland of the springs even after a long dry period. Since the underground hydraulic connection with ponors in the Rakitno, Tribistovo and Posuško Poljes was found, we may assume that this drainage basin has considerable "hidden" reserves. Groundwater, flowing from the Rakitno Polje, encounters hanging hydrogeological barriers in the areas of Posuško and Imotsko Poljes, resulting in decreasing flow and recharging of the aquifers occurring upstream to the barriers. These are the reasons why we can expect large volumes of groundwater along the northern edge of the Imotsko Polje. This assumption was proven at the spring of Grude where $200 \mathrm{l} / \mathrm{s}$ of groundwater was safely extracted from four drilled wells. The Tihaljina river receives the largest part of its water during a hydrological minimum $\left(4.6 \mathrm{~m}^{3} / \mathrm{s}\right)$ from the river Tihaljina spring (No. 14) and the springs Kordić (15), Jakšenica (16) and Klokun (17). All the springs are permanent. Downstream of Klobuk, the appearence of major permanent and intermittent springs is associated with the Ljubuški-Klobuk thrust of Upper Cretaceous limestones over Eocene flysch deposits. The largest springs are: the Podgrab (No. 18), Radišići (21), Vrioštica (20), Studen (19) and the springs of the Studešnica river (No. 22 to 24).

Therefore, taking into account that this area is mainly a "transit" one through which groundwater flows from the north and northeast toward its erosion base, in the south and southeast, toward the Mostarsko Blato and the Tihaljina river, i.e. toward the Neretva river, then the karst zones of western Herzegovina (almost saturated with groundwater) are optimal areas for the exploration for regional water supply (Fig. 2). The promising sites for groundwater extraction for water supply in these zones are: the edges of the Mostarsko Blato and Imotsko Polje, and of the latter, the section
Sovići-Donje Grude and the areas of the Romaljka Cave and Grab, together with the area of intermittent springs of Banje and the karst plateau Čitluk-HamzićiBuhovo. Natural groundwater storage is discharged at numerous permanent and intermittent springs along geologically and morphologically suitable structures in the valleys of the Neretva, Drežnica and Trebižat rivers and along the northwestern edge of the Mostarsko Blato. The total residual dynamic reserves of all those areas amount to about 57 million $\mathrm{m}^{3} /$ year (Table 1). The static groundwater reserves are not yet determined but they also should be taken into consideration.

The discharge of some permanent and intermittent springs can be considerably increased by constructing surface water storage facilities in their drainage basins. By studying morphological and hydrogeological conditions, it has been concluded that a system of microreservoirs along the intermittent stream Ugrovača would result in increasing discharge from the springs situated within the drainage basin of the Mostarsko Blato and, in particular, of the Tihaljina river. The validity of the above assumption is proven by two cases: the spring Studenac and that at Grude. In the both cases, the spring discharge increased two-fold during the recession stage after filling of the storage facilities Salakovac and Tribistovo.

\section{GROUNDWATER CHEMISTRY}

The chemical composition of karst springs reflects the comparatively high homogeneity of carbonate rocks (mostly limestones) and the increased velocity of groundwater flow. The water contains $200-700 \mathrm{mg} / \mathrm{l}$ of total dissolved solids (average $\sim 400 \mathrm{mg} / \mathrm{l}$ ). Alkalinity ranges from 6.5 to 8.0 and the total hardness between 6 and $16 \mathrm{dh}^{\circ}$. The water is of the calcium-hydrocarbonate-type. Cations are represented by $60-90 \% \mathrm{Mg}$-equivalent, whereas $\mathrm{Mg}^{++}$and $\mathrm{Na}^{+}+\mathrm{K}^{+}$vary in content. Anions are represented mostly by $\mathrm{HCO}_{3}^{--}$(80-90\%) with subordinate $\mathrm{Cl}^{-}(10-15 \mathrm{mg} / \mathrm{l})$.

Water derived from dolomites has increased $\mathrm{Mg}^{++}$ (15-50 mg/l) and $\mathrm{SO}_{4}^{--}$(9-24 mg/l) contents. Water from the Flysch formation and "Promina beds" has an increased content $(600-800 \mathrm{mg} / \mathrm{l})$ of the total dissolved solids and variable ionic composition. Hydrocarbonatesulphate type mainly predominates. During the recession period, the content of total dissolved solids is increased by $15-25 \%$.

The total dissolved solids content $(200-300 \mathrm{mg} / \mathrm{l})$ is lowest in springs with a rapid circulation of groundwater such as the permanent or temporary springs in the Neretva river canyon, in the area between Jablanica and Mostar (Fig. 2, no. 1-6). Intermediate contents (300-450 $\mathrm{mg} / \mathrm{l}$ ) of total dissolved solids occur in the springs located along the northeastern margin of the Mostarsko Blato, the lower courses of the Trebižat river and in the river Neretva valley south of Mostar (no. 7-13 and 1824). The increased contents are characteristic for the 
springs located in the upper parts of the Tihaljina river (no. 15-18). These are in full agreement with the geological and hydrogeological conditions as observed in the field. It positively established that groundwater, during its flow from Trebistovo to the Tihaljina river, in the area northeast of Posušje, come in contact with the Sobač Permian-Triassic structure.

The sulphate content increases to $100 \mathrm{mg} / \mathrm{l}$ in the springs with intermediate total dissolved solids and it rapidly changes to $200-600 \mathrm{mg} / \mathrm{l}$ in the springs with increased dissolved solids. The springs Žvatić, Crnašnica and Lištica (no. 10-12), located along the nortwestern margin of the Mostarsko Blato, contain 80$100 \mathrm{mg} / \mathrm{l}$ sulphates indicating deeper circulation of groundwater (up to Lower Triassic clastic sediments) and prolonged storage within the aquifer. The water of the springs in the upper parts of the Tihaljina river contains high quantities of $\mathrm{SO}_{4}^{--}$ions. This spring water was at depth in contact with the Permo-Triassic and Lower Triassic clastic sediments associated with gypsum and sulphate minerals.

The Kordići, Jakšenica, Nezdravica and Klokun springs (no. 15-17) have a total dissolved solid content of between 800 and $1,470 \mathrm{mg} / \mathrm{l}$ and their $\mathrm{SO}_{4}^{--}$content ranges between $200-600 \mathrm{mg} / \mathrm{l}$. These are $\mathrm{HCO}_{3}-\mathrm{SO}_{4}$ or $\mathrm{SO}_{4}-\mathrm{HCO}_{3}$ waters of the calcium-magnesium type. The largest is the Klokun spring $\left(Q_{\min }=3 \mathrm{~m}^{3} / \mathrm{s}\right)$ which has $1,100-1,470 \mathrm{mg} / \mathrm{l}$ of total dissolved solids.

The stable isotope compostition of groundwater has not yet been determined in fresh groundwater from Bosnia and Herzegovina. However, isotopic measurements were carried out on thermo-mineral waters, but such waters have not been encountered so far in the studied part of Bosnia and Herzegovina.

\section{CONCLUSION}

The variety and changes in geological, geomorphological and hydrometeorlogical features resulted in complex hydrogeological conditions of western Herzegovina. These conditions, in a regional sense, are represented by the Orogenic Accumulated Karst with the highly elevated mountainous massifs of Čvrsnica and Čabulja at the north and lower mountains at the south, mutually divided by karst poljes and canyons of intermittent or permanent surface streams.

The dolomites occurring in the area of Diva, Grabovica, the river Drežanka and the springs in Lištica have a significant hydrogeological function - they direct groundwater flows. The Promina formation, occurring between Studena Vrela and Rakitno, and the Eocene flysch, stretching along the overthrust LjubuškiKlobuk, similarly behave. Narrow zones of Eocene deposits stretching along a line from Mostar to the Duvanjsko Polje function as partial barriers. Dolomites, when composing the cores of anticlines, act as relative hydrogeological barriers for groundwater flow. The degree of their impermeability increases with depth.
Groundwater flows eastwardly to the Neretva river canyon and southeastwardly toward the Mostarsko Blato and the river Tihaljina. Along this path, the groundwater encounters larger or smaller barriers and becomes extractable at marginal parts of the Mostarsko Blato, along the northeastern edge of the Imotsko Polje and on the karst plateau Čitluk-Hamzići-Rasno.

Groundwater is extracted, first, at the karst springs and used for regional water supply systems (the town of Mostar from the spring Studenac and the river Radobolja spring, the towns of Čapljina and Čitluk from the river Studenčica spring, the Commune Široki Brijeg from the river Lištica spring etc.). Groundwater is also extracted by drilled wells in suitable zones. Good results were obtained at the permanent spring of Grude and at the southern edge of the Mostarsko Blato. Even better results are expected on the karst plateau Čitluk-Hamzići-Rasno.

Analysis of the well and geophysical exploration data and by observing and measuring rock fissures in mine shafts and galleries in the Tribistovo Polje, suggests that the permeability and karstification of rocks is very high down to a depth of 200-300 m below which both decrease rapidly. This cannot be generalized because, in some parts of the deep karst, there are caverns and fissures through which groundwater flows and these occur below the erosion base of the river Neretva. This was observed at the left bank of the hydro power storage facility at Salakovac and in siphonal conduits in the hinterland of the spring Studenac.

For the High Karst region of western Herzegovina, it was found that the recent karstification occurred occasionally even below the erosion base of active springs. The neotectonic movements which occurred at the end of the Pliocene and in the Pleistocene caused such phenomena. The middle section of the river Neretva rapidly excavated its bed during this time as confirmed by remnants of Pleistocene conglomerates lying 50 to $80 \mathrm{~m}$ above the river bed. Therefore, certain karst processes were developing rapidly but nevertheless most of them occurred above the surface stream. However, karstification is considerably deeper than the altitude of the sites where groundwater discharges into the areas of the rivers Neretva, Tihaljina and Lištica. This was discovered from the boreholes at the southern edge of Mostarsko Blato, in the Imotsko Polje and at Salakovac and Studenac in the river Neretva valley. By exploring and extracting the residual and static reserves, these "hidden" groundwater reserves can be used. A suitable fact is that they occur close to major future users.

\section{REFERENCES}

BOJANIĆ, L., IVIČIĆ, D. \& BATIĆ, V. (1981): Hidrogeologija Imotskog polja s osvrtom na njegov značaj u regionalnom smislu.- Geol. vjesnik, 34, 121-127. 
DŽEMAL, M. \& ZAHIROVIĆ, S. (1985): Projekt Mostarsko Blato - kratak prikaz.- Poslovna zajednica Mostarsko Blato i HE na Neretvi, Jablanica, Spec. ed., 153 p., Mostar.

ĐERKOVIĆ, B. (1970): Rezultati hidrogeoloških istraživanja na krškim poljima zap. Hercegovine.Prvi kolokvij o geologiji Dinarida, Ljubljana, 2, 145-154.

ĐUROVIĆ, M. (1964): Hidrogeološka studija i melioracija Mostarskog Blata.- Građevinar, 2, Zagreb.

HERAK, M. (1977): Tecto-genetic approach to the classification of karst terrains.- Krš Jugosl., 9/4, 227-238, Zagreb.

IVANKOVIĆ, I. \& KOMATINA, M. (1976): Hidrogeološke metode procjene podzemne akumulacije.- Zbornik Jugosl.-amer. simp. "Hidrografija i vodno bogatstvo krša”, Dubrovnik, 1975, 151-176, Sarajevo.

JOSIPOVIĆ, J. (1974): Osnovne hidrogeološke odlike teritorija BiH-e.- Zbornik radova 3. jugosl. simp. o hidrogeol. i inž. geol., Opatija, 133-149.

KOMATINA, M. (1975): Hidrogeološke odlike slivova centralnodinaridskog karsta.- Geozavod Beograd, Spec. ed., 138 p, Beograd.

LUIS, C. (1976): Introduction a 1'hydraulique des roches.- Univ. Pierre et Marie Curie, 138 p., Paris.
MIKULIĆ, S. \& TRUMIĆ, A. (1969): Akumulirane vode na kršu i problemi njenog optimalnog iskorištavanja.- Krš. Jugosl., 6, 279-301, Zagreb.

RISTIĆ, D. (1976): Prilozi proučavanju vodnog režima plavljenih kraških poja.- Zbornik Jugosl.-amer. simp. "Hidrogeologija i vodno bogatstvo krša", Dubrovnik, 1975, 403-421, Sarajevo.

SLIŠKOVIĆ, I. (1984): Geološko-hidrogeološke karakteristike ležišta boksitne rude Trobukva-Studena vrela i mogućnost smanjenja dotoka vode u jamske prostorije.- Zbornik VIII jugosl. simp. o hidrogeol. i inž. geol., Budva, 559-573.

SLIŠKOVIĆ, I. (1986): Mogućnosti vodosnabdijevanja iz neogenih bazena u visokom Kršu.- XI kongres geol. Jugosl., Tara, 5, 109-129, Beograd.

SLIŠKOVIĆ, I. (1991): Hidrogeološki odnosi u čvrstim stijenama Bosne i Hercegovine.- Unpublished Ph.D. Thesis, 205 p., University of Zagreb.

ŠARIN, A. (1983): Hidrogeologija Krškog regiona.- In: IVKOVIĆ, A., ŠARIN, A. \& KOMATINA, M.: Tumač za Hidrogeološku kartu SFR Jugoslavije, 1:500.000. Sav. geol. zavod, 62-101, Beograd.

ŠARIN, A. (1984): Hydrogeological regional classification of the Karst in Yugoslavia.- In: MIJATOVIĆ, B. (ed.): Hydrogeology of the Dinaric Karst. Heise Verlag, 42-53, Hannover.

Manuscript received June 10, 1992.

Revised manuscript accepted November 7, 1994. 
